\title{
Uncontrolled variables in frying studies: differences in repeatability between thermoxidation and frying experiments
}

\author{
By Eliana Rodrigues Machado', Susana Marmesat ${ }^{2}$, Shirley Abrantes ${ }^{1}$ \\ and Carmen Dobarganes ${ }^{2}$
}

\author{
${ }^{1}$ Instituto Nacional de Controle de Qualidade em Saúde (FIOCRUZ), Río de Janeiro, Brasil. \\ ${ }^{2}$ Instituto de la Grasa (CSIC), Sevilla, España \\ * To whom correspondence should be addressed
}

\section{RESUMEN}

Variables de difícil control en los estudios de fritura: Diferencias en repetitividad entre experimentos de termoxidación y de fritura.

Se estudia la repetibilidad de los resultados obtenidos en el calentamiento de los aceites y grasas a temperatura elevada utilizando aceite de palma, aceite de soja y aceite de soja parcialmente hidrogenado. Partiendo de la repetibilidad de las determinaciones analíticas utilizadas para la evaluación de la degradación de los aceites y grasas a elevada temperatura, el análisis de compuestos polares y de su distribución en polímeros de triglicéridos, triglicéridos monómeros oxidados y diglicéridos, se analizan las desviaciones obtenidas durante el tratamiento termoxidativo en condiciones estándar (Rancimat a $180^{\circ} \mathrm{C}$ durante 25 horas) y durante la fritura de patatas en freidoras domésticas en condiciones bien controladas. Los resultados indican la existencia de diferencias significativas en el comportamiento de los aceites en el tratamiento termoxidativo en ausencia de alimentos aunque no fue posible encontrar diferencias significativas en la fritura discontinua cuando se realizan los triplicados en distintas freidoras, debido a las elevadas desviaciones obtenidas entre ensayos. En un posterior ensayo con aceite de palma utilizando la misma freidora para los tres ensayos de frituras se obtuvieron menores desviaciones. Los resultados indican la existencia de variables de difícil control entre las que se apuntan diferencias de temperatura media debido a las diferencias en los ciclos de calentamiento/enfriamiento a temperatura elevada.

PALABRAS-CLAVE: Compuestos polares - Fritura - Repetibilidad - Termoxidación.

\section{SUMMARY}

Uncontrolled variables in frying studies: differences in repeatability between thermoxidation and frying experiments

Palm oil, soybean oil and partially hydrogenated soybean oil were used to define the repeatability of oil degradation under thermoxidation in the absence of food and during the frying of potatoes. Total polar compounds and their constituent polymeric triglycerides, oxidized monomeric triglycerides and diglycerides were analyzed. The oils were thermoxidized under standard conditions in a Rancimat apparatus at $180^{\circ} \mathrm{C}$ for 25 hours. Discontinuous frying experiments were carried out in triplicate in three apparently identical domestic fryers. Five batches of potatoes were fried per day in each fryer. Oils were heated at $180^{\circ} \mathrm{C}$ in periods of $5 \mathrm{~h}$ per day during 5 consecutive days so that the total heating period was
$25 \mathrm{~h}$. Repeatability was high in the thermoxidation assays and rather low in the frying experiments. Significant differences between the oils were found in the thermoxidation experiments, while no significant differences were found in the frying assays due to large standard deviations. The participation of variables related to the fryer performance which are difficult to control, was deduced. Among them, differences in the heating/cooling cycles at high temperature might be important. The contribution of fryer performance to the decreased repeatability was confirmed in further frying experiments with palm oil. Results showed that repeatability for the same fryer was higher than that obtained when different fryers were considered.

KEY-WORDS: Frying - Polar compounds - Repeatability - Thermoxidation.

\section{INTRODUCTION}

Oils with a low degree of unsaturation such as hydrogenated oils and palm olein are preferred by the catering industry and snack manufacturers due to their high thermostability (Kochhar, 2001). However, minor components exerting antioxidative or prooxidative action also contribute to oil performance. In this regard, different reports have shown that oils clearly differing in their degree of unsaturation exhibited similar behavior at high temperatures (Márquez-Ruiz et al, 1995; Warner and Knowlton, 1997; Warner et al., 1997; Norman et al., 2003; Norman et al, 2006).

Due to the high number of variables acting and interacting between them it is not possible in practice to reproduce the results of frying experiments in different laboratories. The food composition and the initial quality of the frying oil are examples of variables that cannot be reproduced. As a result, many research groups working on the subject probably have unpublished and unexplained data obtained in discontinuous frying experiments. Unfortunately, there is no available information on anomalous results obtained in research experiments, which would be of great interest for many researchers.

Towards different aims, numerous investigations on discontinuous frying have been reported, but the repeatability of frying experiments has not been documented. Performance of different oils is 
normally assessed in the absence of food and a high repeatability is obtained provided that wellestablished standard conditions are applied (Barrera et al., 1997; Steel et al., 2005; Steel et al, 2006).

The objective of this study was to compare the repeatability of oil degradation in well-controlled thermoxidation and frying experiments. Palm oil (PO), soybean oil (SO) and partially hydrogenated soybean oil (PHSO) were used. PO was selected due to its recognized good frying performance, while SO and PHSO were studied because they are good examples of oils of high and low degree of unsaturation, respectively, and similar unsaponifiable matter. The oil degradation was assessed by determining total polar compounds and their constituent polymeric triglycerides, oxidized monomeric triglycerides and diglycerides. The oils were thermoxidized under standard conditions in a Rancimat device at $180{ }^{\circ} \mathrm{C}$ for 25 hours. Discontinuous frying experiments were carried out in triplicate in three identical domestic fryers. Potatoes were fried at $180{ }^{\circ} \mathrm{C}$ in periods of 5 $\mathrm{h}$ per day during 5 consecutive days so that the total heating period was $25 \mathrm{~h}$.

\section{EXPERIMENTAL PART}

\section{Samples}

Refined SO and PHSO were acquired in a local Brazilian market, while PO was donated by the company «Grupo Agropalma» (Tailândia, Pará, Brazil).

Raw potatoes, variety Jaerla, were acquired in a local Spanish market.

\section{Sample treatment}

\section{a) Thermal oxidation}

An aliquot of $8 \pm 0.01 \mathrm{~g}$ of each oil was weighed into Rancimat tubes and the tubes were heated at $180 \pm 1{ }^{\circ} \mathrm{C}$ for $25 \mathrm{~h}$ in the heating block of a 679 Rancimat (Metrohm, Switzerland). The tubes were left open and no bubbling of air was applied during heating. The thermoxidized samples were kept at $-30{ }^{\circ} \mathrm{C}$ until analyses. Triplicate experiments were performed to determine repeatability. This procedure was described in detail, including reproducibility data, in a previous publication (Barrera-Arellano et al., 1997).

\section{b) Frying Procedure}

Three identical commercial fryers for domestic purposes (Taurus Gourmet) were used in this study. A volume of $600 \mathrm{~mL}$ of each oil was used in each fryer to prepare $500 \mathrm{~g}$ of fried potatoes per oil and day. Five batches of $100 \mathrm{~g}$ of raw potatoes (1 batch per hour) were fried evary day in five consecutive days so that the total heating period was $25 \mathrm{~h}$.

Potatoes were peeled, cut into homogeneous strips and washed with water. The frying time was 3 min per batch. The initial frying temperature was around $180^{\circ} \mathrm{C}$ and no replenishment of oil was considered. Samples of oils were taken out at the end of the heating period. The surface-to-oil volume ratio changed from around $0.3 \mathrm{~cm}^{-1}$ to around 0.4 $\mathrm{cm}^{-1}$ at the end of the experiment.

Frying experiments were carried out in triplicate. In order to include the deviations due to the fryers, a different fryer was used for each oil from one experiment to another.

In a second set of experiments, the same conditions were applied to palm oil and triplicate experiments were carried out in a same fryer.

\section{Analytical determinations}

The following AOCS (1996) or IUPAC (1992) Official Methods were used to characterize the oils used: Oxidative Stability (AOCS Method Cd 12b-92, using Rancimat equipment at $110^{\circ} \mathrm{C}$ ), Free Fatty Acids (AOCS Method Ca 5a-40), Peroxide Value (AOCS Method Cd 8b-90), Unsaponifiable Matter (AOCS Method Ca 6a-40) Fatty Acid Composition (AOCS Method $\mathrm{Ce}$ 1-62) and Tocopherols and Tocotrienols (IUPAC 2.432).

Quantification of total polar compounds and their distribution. The content of total polar compounds was determined gravimetrically following the method proposed by the IUPAC (IUPAC, 1992) with slight modifications (Dobarganes et al., 1988). Briefly, non-polar and polar fractions were separated from $1 \mathrm{~g}$ of sample by silica column chromatography $\left(20 \mathrm{~g}\right.$ silica- $\left.\mathrm{H}_{2} \mathrm{O}, 95: 5(\mathrm{w} / \mathrm{w})\right)$. The non-polar fraction containing unaltered triglycerides was eluted with $150 \mathrm{~mL}$ of $\mathrm{n}$-hexane/diethyl ether $(90: 10, v / v)$. A second fraction, comprised of total polar compounds, was eluted with $150 \mathrm{~mL}$ of diethyl ether. Efficiency of the separation was checked by thin layer chromatography using hexane/diethyl ether/acetic acid (80:20:1, v/v/v) for the development of plates and exposure to iodine vapor to reveal the spots. After evaporation of solvents, both fractions were weighed and the polar fraction was dissolved in diethyl ether for the analysis of polar compound distribution by high-performance size exclusion chromatography (HPSEC). An HPSEC chromatograph equipped with a Rheodyne $7725 \mathrm{i}$ injector with a $10-\mu \mathrm{L}$ sample loop, a Waters 510 pump (Waters, Milford, MA, USA) and a refractive index detector (Merck, Darmstadt, Germany) was used. The separation was performed on two 100 and $500 \AA$ Ultrastyragel columns $(25 \mathrm{~cm}$ $x 0.77 \mathrm{~cm}$ I.D.) packed with porous, highly crosslinked styrene-divinylbenzene copolymers (film thickness $10 \mathrm{~mm}$ ) (Hewlett-Packard, Avondale, PA, USA) connected in series, with tetrahydrofuran (1 $\mathrm{mL} / \mathrm{min}$ ) as the mobile phase.

\section{Statistical analysis}

Statistical analysis was performed by Microsoft Excel 2000 (Microsoft Co., WA, USA). Comparisons 
between means were made by the Student's $t$ test. Significance was defined at $P<0.05$. Analytical determinations were performed in triplicate in the initial oils while just one was considered in the treated samples in each replicate of experiments.

\section{RESULTS AND DISCUSSION}

Table 1 shows the physico-chemical characteristics of the three oils used in this study. Analyses showed values for free fatty acids, peroxide value and unsaponifiable matter typically found in fresh refined oils. From the stability index values and fatty acid composition, a better frying performance would be expected for PO and PHSO. Finally, it can be observed that the content of tocopherols was of the same order in SO and PHSO, while PO was characterized by the presence of tocotrienols as major natural antioxidants.

Table 2 summarizes the content of polar compounds and their distribution in polymers, oxidized monomers and diglycerides found in the initial oils. As can be observed, the percentage of polar compounds was slightly higher in $\mathrm{PO}$ due to the high amount of diglycerides, which is typically found in palm oils (Goh and Timms, 1985). In relation to analytical repeatability, the results are in agreement with those found in the IUPAC standard method (Dobarganes et al, 2000).

Table 1

Physico-chemical characteristics of the initial oils.

\begin{tabular}{|c|c|c|c|c|}
\hline & & Palm oil & Soybean oil & $\begin{array}{c}\text { Partially hydrogenated } \\
\text { soybean oil }\end{array}$ \\
\hline \multicolumn{2}{|c|}{$\begin{array}{l}\text { Free Fatty Acids } \\
\text { (\% oleic acid) }\end{array}$} & $0.08 \pm 0.03$ & $0.07 \pm 0.0$ & $0.09 \pm 0.01$ \\
\hline \multicolumn{2}{|c|}{$\begin{array}{l}\text { Peroxide Value } \\
\text { (meq } \mathrm{O}_{2} / \mathrm{kg} \text { ) }\end{array}$} & $2.70 \pm 0.07$ & $0.67 \pm 0.01$ & $0.56 \pm 0.09$ \\
\hline \multicolumn{2}{|c|}{$\begin{array}{c}\text { Oxidative Stability } \\
\left(\mathrm{h}, 110^{\circ} \mathrm{C}\right)\end{array}$} & $47.9 \pm 2.2$ & $7.6 \pm 0.5$ & $17.7 \pm 1.0$ \\
\hline \multicolumn{2}{|c|}{$\begin{array}{l}\text { Unsaponifiable Matter } \\
(\%, \mathrm{~m} / \mathrm{m})\end{array}$} & $0.49 \pm 0.09$ & $0.63 \pm 0.01$ & $0.75 \pm 0.04$ \\
\hline $\begin{array}{c}\text { Major Fatty } \\
\text { Acids } \\
(\%, \mathrm{~m} / \mathrm{m})\end{array}$ & $\begin{array}{l}\text { C 16:0 } \\
\text { C 18:0 } \\
\text { C 18:1 } \\
\text { C } 18: 2 \\
\text { C } 18: 3\end{array}$ & $\begin{array}{c}42.3 \pm 0.5 \\
4.8 \pm 0.2 \\
41.9 \pm 1.0 \\
9.0 \pm 0.0 \\
<0.4\end{array}$ & $\begin{array}{c}11.3 \pm 0.1 \\
3.5 \pm 0.1 \\
23.1 \pm 0.1 \\
54.2 \pm 0.1 \\
6.8 \pm 0.1\end{array}$ & $\begin{array}{c}11.3 \pm 0.4 \\
9.5 \pm 0.4 \\
48.6 \pm 0.6 \\
27.3 \pm 2.1 \\
2.4 \pm 0.4\end{array}$ \\
\hline $\begin{array}{l}\text { Tocopherols/ } \\
\text { tocotrienols } \\
\text { (mg/kg) }\end{array}$ & $\begin{array}{c}\text { Total } \\
\alpha-T F \\
\alpha-\text { TT } \\
\beta-T F \\
\gamma-T F / T T \\
\delta \text {-TF/TT }\end{array}$ & $\begin{array}{c}840 \\
149 \pm 8 \\
- \\
13 \pm 3 \\
536^{\star} \pm 19 \\
142^{\star} \pm 5\end{array}$ & $\begin{array}{c}933 \\
222 \pm 30 \\
201 \pm 28 \\
- \\
256 \pm 37 \\
254 \pm 38\end{array}$ & $\begin{array}{c}997 \\
158 \pm 24 \\
- \\
45 \pm 1 \\
620 \pm 98 \\
174 \pm 20\end{array}$ \\
\hline
\end{tabular}

mean $\pm S D(n=3) ; T F$, tocopherol; TT, tocotrienol; * $\gamma$ and $\delta$ tocotrienols.

Table 2

Total polar compounds and their distribution in the initial oils: repeatability of analytical determination.

\begin{tabular}{|c|c|c|c|c|c|}
\hline \multirow{3}{*}{ SAMPLE } & & \multicolumn{4}{|c|}{ Polar Compounds (wt\% on oil) } \\
\hline & & \multirow{2}{*}{ TOTAL } & \multicolumn{3}{|c|}{ Distribution } \\
\hline & & & Polymers & $\begin{array}{l}\text { Oxidized } \\
\text { monomers }\end{array}$ & Diglycerides \\
\hline PALM OIL & $\begin{array}{c}\text { Mean } \\
\text { Standard deviation } \\
\text { Coefficient of variation (\%) }\end{array}$ & $\begin{array}{l}6.1^{\mathrm{a}} \\
0.3 \\
4.9\end{array}$ & $\begin{array}{c}0.4^{\mathrm{a}} \\
0,02 \\
3,8\end{array}$ & $\begin{array}{c}0.7^{\mathrm{a}} \\
0.3 \\
42.9\end{array}$ & $\begin{array}{l}4.6^{\mathrm{a}} \\
0.2 \\
4.3\end{array}$ \\
\hline SOYBEAN OIL & $\begin{array}{c}\text { Mean } \\
\text { Standard deviation } \\
\text { Coefficient of variation (\%) }\end{array}$ & $\begin{array}{l}5.1^{\mathrm{b}} \\
0.1 \\
2.0\end{array}$ & $\begin{array}{l}0.5^{\mathrm{a}} \\
0.06 \\
12.0\end{array}$ & $\begin{array}{c}2.9^{b} \\
0.3 \\
10.3\end{array}$ & $\begin{array}{l}1.3^{b} \\
0.1 \\
7.7\end{array}$ \\
\hline $\begin{array}{l}\text { HYDROGENATED } \\
\text { SOYBEAN OIL }\end{array}$ & $\begin{array}{c}\text { Mean } \\
\text { Standard deviation } \\
\text { Coefficient of variation (\%) }\end{array}$ & $\begin{array}{l}4.4^{b} \\
0.4 \\
9.1\end{array}$ & $\begin{array}{c}0.9^{b} \\
0.06 \\
6.7\end{array}$ & $\begin{array}{c}1.7^{\mathrm{c}} \\
0.3 \\
17.6\end{array}$ & $\begin{array}{l}1.3^{b} \\
0.1 \\
7.7\end{array}$ \\
\hline
\end{tabular}


Table 3 shows the results of the thermoxidation experiments. The mean values correspond to samples heated in three Rancimat vessels (one analytical determination per vessel). Thus, the deviations were, as expected, higher than those given in Table 2 as they also included differences due to the heat treatment. There were no significant differences between the polar compound percentages in $\mathrm{PO}$ and PHSO, while the most unsaturated oil, i.e., SO, underwent a significantly higher degradation. The level of diglycerides remained unchanged during thermoxidation (see Table 2 for initial values) due to the absence of moisture. In parallel, the standard deviations for diglycerides were of the same order as those found in the initial oils.

Table 4 summarizes the results from the frying experiments. In comparison with the thermoxidation experiments, standard deviations were rather high. As expressed in terms of coefficients of variation, repeatability was $25.0-36.0 \%$ for total polar compounds. As a result, no significant differences were found between the oils. It was again interesting to check that the lowest standard deviations were obtained for diglycerides. This is mainly due to the low level of hydrolysis in all the samples in spite of the high water content of the potatoes (around $80 \%$ ), as can be deduced by comparing the results in Table 4 with those of the initial oils (Table 2). Accordingly, the increase in polar compounds was due to the formation of polymers and oxidized monomers.

Table 5 shows the variables involved with known differences between thermoxidation and frying experiments. As can be observed, besides the changing surface-to-volume ratio typical of frying experiments without the addition of fresh oil to compensate the amount absorbed by the food, the great differences in temperature stood out. As discussed later, the range of temperatures between and during the frying operations were the same for

Table 3

Total polar compounds and their distribution in the thermoxidized oils (25 hours at $180{ }^{\circ} \mathrm{C}$ ): repeatability of thermoxidation experiments in a rancimat device.

\begin{tabular}{|c|c|c|c|c|c|}
\hline \multirow{3}{*}{ SAMPLE } & & \multicolumn{4}{|c|}{ Polar Compounds (wt\% on oil) } \\
\hline & & \multirow{2}{*}{ TOTAL } & \multicolumn{3}{|c|}{ Distribution } \\
\hline & & & Polymers & $\begin{array}{l}\text { Oxidized } \\
\text { monomers }\end{array}$ & Diglycerides \\
\hline PALM OIL & $\begin{array}{c}\text { Mean } \\
\text { Standard deviation } \\
\text { Coefficient of variation (\%) }\end{array}$ & $\begin{array}{c}14.2^{\mathrm{a}} \\
2.1 \\
14.8\end{array}$ & $\begin{array}{l}5.2 \\
0.3 \\
\mathbf{5 . 8}\end{array}$ & $\begin{array}{c}4.2^{\mathrm{a}} \\
1.7 \\
40.5\end{array}$ & $\begin{array}{l}4.5^{\mathrm{a}} \\
0.1 \\
2.2\end{array}$ \\
\hline SOYBEAN OIL & $\begin{array}{c}\text { Mean } \\
\text { Standard deviation } \\
\text { Coefficient of variation (\%) }\end{array}$ & $\begin{array}{c}38.5^{\mathrm{b}} \\
1.2 \\
3.1\end{array}$ & $\begin{array}{c}24.2^{b} \\
1.0 \\
4.1\end{array}$ & $\begin{array}{c}12.7^{b} \\
0.3 \\
2.4\end{array}$ & $\begin{array}{c}1.2^{b} \\
0,03 \\
2,2\end{array}$ \\
\hline $\begin{array}{l}\text { HYDROGENATED } \\
\text { SOYBEAN OIL }\end{array}$ & $\begin{array}{c}\text { Mean } \\
\text { Standard deviation } \\
\text { Coefficient of variation (\%) }\end{array}$ & $\begin{array}{c}15.4^{\mathrm{a}} \\
0.9 \\
5.8\end{array}$ & $\begin{array}{l}7.6^{c} \\
0.5 \\
6.6\end{array}$ & $\begin{array}{l}5.9^{\mathrm{a}} \\
0.5 \\
\mathbf{8 . 5}\end{array}$ & $\begin{array}{c}1.2^{b} \\
0.05 \\
3.7\end{array}$ \\
\hline
\end{tabular}

$\mathrm{n}=3$; Different superscript letters for values in the same column denote significant differences $(\mathrm{P}<0.05)$.

Table 4

Total polar compounds and their distribution in the used frying oils (25 hours at $180^{\circ} \mathrm{C}$ ): repeatability of frying experiments.

\begin{tabular}{|c|c|c|c|c|c|}
\hline \multirow{3}{*}{ SAMPLE } & & \multicolumn{4}{|c|}{ Polar Compounds (wt\% on oil) } \\
\hline & & \multirow{2}{*}{ TOTAL } & \multicolumn{3}{|c|}{ Distribution } \\
\hline & & & Polymers & $\begin{array}{l}\text { Oxidized } \\
\text { monomers }\end{array}$ & Diglycerides \\
\hline PALM OIL & $\begin{array}{c}\text { Mean } \\
\text { Standard deviation } \\
\text { Coefficient of variation (\%) }\end{array}$ & $\begin{array}{c}32.6^{\mathrm{a}} \\
9.6 \\
29.5\end{array}$ & $\begin{array}{c}16.0^{\mathrm{a}} \\
6.2 \\
38.7\end{array}$ & $\begin{array}{c}10.9^{\mathrm{a}} \\
3.3 \\
30.1\end{array}$ & $\begin{array}{l}5.1^{\mathrm{a}} \\
0.2 \\
4.1\end{array}$ \\
\hline SOYBEAN OIL & $\begin{array}{c}\text { Mean } \\
\text { Standard deviation } \\
\text { Coefficient of variation (\%) }\end{array}$ & $\begin{array}{l}35.6^{\mathrm{a}} \\
12.8 \\
36.0\end{array}$ & $\begin{array}{c}22.2^{\mathrm{a}} \\
9.4 \\
42.2\end{array}$ & $\begin{array}{l}10.7^{\mathrm{a}} \\
3.7 \\
34.3\end{array}$ & $\begin{array}{l}1.8^{b} \\
0.2 \\
8.3\end{array}$ \\
\hline $\begin{array}{l}\text { HYDROGENATED } \\
\text { SOYBEAN OIL }\end{array}$ & $\begin{array}{c}\text { Mean } \\
\text { Standard deviation } \\
\text { Coefficient of variation (\%) }\end{array}$ & $\begin{array}{c}34.4^{\mathrm{a}} \\
8.9 \\
25.9\end{array}$ & $\begin{array}{c}20.0^{\mathrm{a}} \\
6.9 \\
34.7\end{array}$ & $\begin{array}{c}12.3^{\mathrm{a}} \\
1.9 \\
15.6\end{array}$ & $\begin{array}{c}1.8^{b} \\
0.2 \\
12.6\end{array}$ \\
\hline
\end{tabular}

$n=3$; Different superscript letters for values in the same column denote significant differences $(P<0.05)$. 
Table 5

Comparative conditions between thermoxidation and frying experiments.

\begin{tabular}{lcc}
\hline & & \multicolumn{1}{c}{ Frying } \\
\cline { 3 - 4 } & Thermoxidation & $\begin{array}{c}\text { Between } \\
\text { frying } \\
\text { operations }\end{array}$ \\
\hline $\begin{array}{l}\text { Temperature } \\
\text { range }\left({ }^{\circ} \mathrm{C}\right)\end{array}$ & $179-181^{1}$ & $167-192 \quad 122-159$ \\
$\begin{array}{l}\text { Surface/ oil } \\
\text { volume }\left(\mathrm{cm}^{-1}\right)\end{array}$ & 0.4 & From 0.29 to $0.38^{2}$ \\
$\begin{array}{l}\text { Period of } \\
\text { heating }(\mathrm{h})\end{array}$ & 25 & 25 \\
$\begin{array}{l}\text { Fried } \\
\text { potatoes }(\mathrm{kg})\end{array}$ & 0 & 2.5 \\
\hline
\end{tabular}

${ }^{1}$ Rancimat specifications; ${ }^{2}$ Changes due to the oil absorbed by potatoes.

the three fryers, although differences between the mean temperatures throughout the whole experiment (25-h heating) could be deduced.

The Rancimat apparatus allowed for excellent control due to its technical characteristics, i.e. standard vessels and homogeneous temperature in the samples by virtue of the good performance of the heating block. As to the discontinuous frying experiments, the best possible control was established, as summarized in the following points:

a) The three fryers were used simultaneously. For each oil, a different fryer was used in each replicate of experiments. Thus, possible minor differences between the fryers were compensated.

b) Temperature was measured more than 100 times during the frying experiments and no difference between the maximum and minimum temperature was found in the absence of food.

c) The same amount of potatoes was fried in each frying operation and identical lots of potatoes were used. The total range of temperatures during frying was practically the same, although great differences were observed between frying operations.

In relation to temperature, the main uncontrollable aspects observed can be summarized as follows:

1) Differences in the fryer temperature sensors. Even though in the absence of food the differences between the maximum and minimum temperature were very low, differences in the temperature sensor action were observed. Thus, the heating/cooling cycles at a high temperature -between 15 and 30 cycles per hour- were variable and uncontrollable, and might influence the unknown mean temperature.

2) Differences in temperature during frying operations. As the frying operations were carried out simultaneously, it was impossible to set the same temperature for the three fryers when the potatoes were introduced into the heated oil. As it is well known, there is a rapid decrease in temperature in the frying oil due to both the food temperature and the temperature inside the potatoes while the moisture is evaporating, not exceeding $100^{\circ} \mathrm{C}$. Under the conditions applied, temperature decreased around 50$60{ }^{\circ} \mathrm{C}$ from the starting and variable point and differences of around $15^{\circ} \mathrm{C}$ were observed for the minimum temperature during frying.

3) Differences in temperature might be translated into differences in the oil absorbed by the food, which in turn may have an effect on the surface-to-oil volume ratio in 25-hour experiments. However, this fact was not observed.

A last experiment with palm oil was carried out by exerting a more strict control. In order to minimize differences, the same fryer was used for the triplicates and the potatoes were introduced into the heated oil when the maximum temperature was reached, i.e., when the temperature sensor switched off. The results are summarized in Table 6. Lower standard deviations than those shown in Table 4 were found, which seems to indicate that even being apparently identical, small uncontrolled differences in the fryer design had an effect on the results obtained. However, the influence of variables other than those controlled cannot be excluded as the standard deviations found were still higher than those of thermoxidation in the absence of food (Table 3).

\section{CONCLUSIONS}

The repeatability of thermoxidation experiments in the absence of food was very high and significant differences in the performance of the three oils were found. Nevertheless, such differences were not observed in frying experiments carried out in small domestic fryers due to the high standard deviations found.

Overall, the results obtained support the need for a maximum control in frying experiments when comparing fats and oils without replicates and the advantages or even the requirement of a parallel thermoxidation assay to confirm the results found in frying experiments.

\section{ACKNOWLEDGMENTS}

This research work was supported by Junta de Andalucía and MCYT (Project AGL 2004-00148). Eliana Rodrigues from the Instituto Nacional de Controle de Qualidade em Saúde/ FIOCRUZ was supported by a fellowship from Coordenação de Aperfeiçoamento de Pessoal de Nível Superior do Brasil (CAPES). The authors thank Mercedes Giménez for assistance. 
Table 6

Total polar compounds and their distribution in the palm oil $\left(25\right.$ hours at $\left.180{ }^{\circ} \mathrm{C}\right)$ : repeatability of experiments in the same fryer.

\begin{tabular}{|c|c|c|c|c|c|}
\hline \multirow{3}{*}{ SAMPLE } & & \multicolumn{4}{|c|}{ Polar Compounds (wt\% on oil) } \\
\hline & & \multirow{2}{*}{ TOTAL } & \multicolumn{3}{|c|}{ Distribution } \\
\hline & & & Polymers & $\begin{array}{l}\text { Oxidized } \\
\text { monomers }\end{array}$ & Diglycerides \\
\hline PALM OIL & $\begin{array}{c}\text { Mean } \\
\text { Standard deviation } \\
\text { Coefficient of variation (\%) }\end{array}$ & $\begin{array}{c}28.0 \\
3.3 \\
11.9\end{array}$ & $\begin{array}{c}11.1 \\
1.3 \\
11.8\end{array}$ & $\begin{array}{c}10.40 \\
1.7 \\
16.4\end{array}$ & $\begin{array}{l}5.0 \\
0.1 \\
3.0\end{array}$ \\
\hline
\end{tabular}

$\mathrm{n}=3$; Different superscript letters for values in the same column denote significant differences $(P<0.05)$.

\section{REFERENCES}

AOCS - American Oil Chemists' Society. 1996. Official methods and recommended practices of the American Oil Chemists' Society. $4^{\text {th }}$ ed., AOCS, Champaign.

Barrera-Arellano D, Márquez-Ruiz G, Dobarganes M.C. 1997 A simple procedure to evaluate the performance of fats and oils at frying temperatures. Grasas y Aceites 48, 231-235.

Dobarganes M.C, Pérez-Camino M.C, Márquez-Ruiz G. 1988. High performance size exclusion chromatography of polar compounds in heated and non-heated fats, Fat Sci Technol. 90, 308-311.

Dobarganes M.C, Velasco J, Dieffenbacher A. 2000. The determination of polar compounds, polymerised triacylglycerols, oxidised triacylglycerols and diacylglycerols in fats and oils. Pure Appl Chem. 72, 1563-1575

Goh E.M, Timms R.E. 1985. Determination of mono and diglycerides in palm oil, olein and stearin. $J$ Am Oil Chem Soc. 62, 730-734.

IUPAC. International Union of Pure and Applied Chemistry. 1992. Methods 2.432 and 2.507 in «Standard methods for the analysis of oils, fats and derivatives». $7^{\text {th }}$ edition, Pergamon Press, Oxford.

Kochhar S.P. 2001. The composition of frying oils. In Rossel JB (ed) Frying: Improving quality. 87-110. Woodhead Publishing Ltd. Cambridge, England.
Márquez-Ruiz G, Tasioula-Margari M, Dobarganes M.C. 1995. Quantitation and distribution of altered fatty acids in frying fats. J Am Oil Chem Soc, 72, 1171-1176.

Normand L, Eskin N.A.M, Przybylski R. 2006.Comparison of the frying stability of regular and high oleic acid sunflower oils. J Am Oil Chem Soc, 83, 331-334.

Normand L, Eskin, N.A.M, Przybylski R. 2003.Comparison of the frying stability of regular and low-linolenic acid soybean oils. J Food Lipids 10, 81-90.

Steel C.J, Dobarganes M.C, Barrera-Arellano D. 2005. The influence of natural tocopherols during thermal oxidation of refined and partially hydrogenated soybean oils. Grasas y Aceites 55, 46-52.

Steel C.J, Dobarganes M.C, Barrera-Arellano D. 2006. Formation of polymerization compounds during thermal oxidation of cottonseed oil, partially hydrogenated cottonseed oil and their blends. Grasas y Aceites 54, 284-291.

Warner K, Knowlton S.1997. Frying quality and oxidative stability of high-oleic corn oils. J Am Oil Chem Soc, 74, 1317-1322.

Warner K, Orr P and Glynn M. 1997. Effect of fatty acid composition of oils on flavor and stability of fried-foods. J Am Oil Chem Soc, 74, 347-356.

Recibido: 9/2/07 Aceptado:11/4/07 